\title{
PENGARUH MODEL PEMBELAJARAN KOOPERATIF TIPE TIME TOKEN ARENDS TERHADAP KETERAMPILAN SOSIAL PESERTA DIDIK DI KELAS
}

\section{THE INFLUENCE OF COOPERATIVE LEARNING MODEL TYPE TIME TOKEN ARENDS TOWARDS STUDENTS'S SOCIAL SKILLS IN THE CLASSROOM}

\author{
Syofi Syofiyah Dewi ${ }^{1}$, Arrofa Acesta ${ }^{2}$, Heru Purnomo ${ }^{3}$ \\ ${ }^{1,2}$ PGSD, FKIP, Universitas Kuningan \\ ${ }^{3}$ PGSD, FKIP, Universitas PGRI Yogyakarta \\ ${ }^{1}$ syofi787@ gmail.com, ${ }^{2}$ arrofa.acesta@uniku.ac.id, ${ }^{3}$ herupurnomo809@ gmail.com
}

\begin{abstract}
Pengutipan: Dewi, S. S., Acesta, A., Purnomo, H. (2020). Pengaruh model pembelajaran kooperatif tipe time token arends terhadap keterampilan sosial peserta didik di kelas. Pedagogi: Jurnal Penelitian Pendidikan, 7 (1), hlm 43-56.
\end{abstract}

Diajukan: 18-05-2020Ｄiterima: 23-05-2020Ｄiterbitkan: 31-05-2020

\begin{abstract}
ABSTRAK
Keterampilan sosial memiliki peran yang sangat penting untuk mendukung suatu interaksi dalam kegiatan pembelajaran. Namun, keterampilan sosial peserta didik di kelas V SDN 1 Purwawinangun masih tergolong rendah. Penelitian ini bertujuan untuk mengetahui apakah model pembelajaran kooperatif tipe Time Token Arends berpengaruh terhadap keterampilan sosial peserta didik di kelas dalam mata pelajaran Ilmu Pengetahuan Sosial kelas V SDN 1 Purwawinangun. Jenis penelitian ini adalah penelitian quasi eksperimen. Instrumen yang digunakan pada penelitian ini adalah lembar observasi. Untuk mengetahui pengaruh model pembelajaran kooperatif tipe Time Token Arends dapat dilihat dari perbedaan kedua rata-rata nilai kelas eksperimen dan kelas kontrol dengan menggunakan uji t dua sampel independen serta dilihat dari peningkatan dengan menggunakan rumus n-gain. Hasil penelitian menunjukkan bahwa terdapat perbedaan rata-rata nilai keterampilan sosial peserta didik antara kelas eksperimen dan kelas kontrol serta peningkatan keterampilan sosial peserta didik di kelas eksperimen lebih tinggi daripada kelas kontrol. Sehingga model kooperatif tipe Time Token Arends berpengaruh terhadap keterampilan sosial peserta didik di kelas pada mata pelajaran Ilmu Pengetahuan Sosial di Kelas V SDN 1 Purwawinangun. Peneliti selanjutnya dapat melakukan penelitian serupa dengan indikator lain dan aspek keterampilan sosial yang lebih kompleks.
\end{abstract}

Kata Kunci: model kooperatif; time token arends; keterampilan sosial di kelas.

\section{ABSTRACT}

Social skills have a very important role to support an interaction in learning activities. But, student's social skills in fifth-grade students of SDN 1 Purwawinangun were relatively low. The aim of this research was to determine whether cooperative learning model type Time Token Arends influenced student's social skills in the classroom on Social Science course in the fifth-grade students of SDN 1 Purwawinangun. The type of this research was quasiexperiment. The instrument used in this research was observation sheets. To determine the influence of cooperative learning model type Time Token Arends could be seen from both the 
Syofi Syofiyah Dewi, Arrofa Acesta, \& Heru Purnomo

PENGARUH MODEL PEMBELAJARAN KOOPERATIF TIPE TIME TOKEN ARENDS TERHADAP KETERAMPILAN SOSIAL PESERTA DIDIK DI KELAS

average score difference of the experimental class and the control class using the independent two-sample t-test, and grading the score increase by using $n$-gain formula. The research result showed that there was an average score difference of a student's social skills between the experimental class and the control class. The increased student's social skills in the experiment class were higher than the control class. So the cooperative learning model type Time Token Arends could influence the students' social skills in the classroom on Social Science course in the fifth-grade students of SDN 1 Purwawinangun. Future researchers can conduct similar research with other indicators and more complex aspects of social skills.

Keywords: cooperative model; time token arends; social skills in the classroom. 


\section{PENDAHULUAN}

Pembelajaran merupakan suatu sistem yang terdiri dari berbagai macam komponen mulai dari komponen tujuan, materi, model atau metode dan evaluasi, yang mana setiap komponen tersebut saling berkaitan satu sama lain. Suatu kegiatan pembelajaran dapat terjadi karena adanya suatu interaksi antara guru dan peserta didik baik di dalam ruangan maupun di luar ruangan. Interaksi yang terjadi tentu saja interaksi dua arah. Sardiman (2004) mengemukakan bahwa komunikasi sebagai interaksi atau komunikasi dua arah yaitu guru bisa berperan sebagai pemberi aksi atau penerima aksi. Sebaliknya siswa, bisa menerima aksi bisa pula pemberi aksi sehingga dialog akan terjadi antara guru dengan siswa dan dalam pola komunikasi ini dapat terjadi hubungan Interpesonal antara guru dan siswa. Hal itu menyebabkan kegiatan pembelajaran akan berjalan sesuai dengan apa yang telah direncanakan dan pencapaian tujuan pembelajaran pun akan lebih mudah untuk dicapai. Adapun ranah-ranah yang harus dicapai pada setiap tujuan pembelajaran terdiri dari ranah sikap (atittude), ranah pengetahuan (knowledge) dan ranah keterampilan (skill) setiap peserta didik.

Dijelaskan lebih rinci oleh Purnomo (2019) bahwa kompetensi yang dicapai peserta didik harus secara aktif mengembangkan apa yang dimiliki dalam dirinya baik itu bakat, minat dan potensi yang ada pada diri peserta didik terutama yang berkaitan dengan knowledge, skill dan attitued yang dimiliki selama mengikuti proses dari awal hingga akhir. Keterampilan sosial merupakan salah satu kompetensi dari ketercapaian otentik yang ditinjau dari aspek kemampuan keterampilan (skill). Keterampilan sosial dapat diartikan sebagai kemampuan untuk dapat berkomunikasi dan berinteraksi secara efektif dengan orang lain.

Keterampilan sosial harus dibiasakan kepada peserta didik khususnya saat kegiatan pembelajaran, karena pada saat kegiatan pembelajaran di kelas, peserta didik berinteraksi dengan temannya dan berinteraksi dengan guru. Interaksi ini jelas perlu dilakukan oleh peserta didik sebagai proses belajar, proses mencari pengalaman belajar. Pembelajaran yang baik akan tercapai jika interaksi antara guru dengan peserta didik maupun peserta didik dengan peserta didik berjalan dengan baik pula. Keterampilan sosial meliputi kemampuan berkomunikasi, menjalin hubungan dengan orang lain, menghargai diri sendiri dan orang lain, perilaku memberi atau menerima umpan balik, memberi atau menerima kritik, bertindak sesuai norma dan aturan yang berlaku (Thalib, 2010).

Keterampilan sosial sebagai sarana untuk memperoleh hubungan yang baik (feedback) dalam berinteraksi dengan orang lain. Pentingnya berbagai macam keterampilan sosial bagi saat ini sangat diperlukan dan ditanamkan pada peserta didik salah satu caranya yaitu dengan diterapkan dalam proses pembelajaran. Keterampilan sosial peserta didik dalam kegiatan pembelajaran dapat dilihat melalui beberapa indikator yang saling berkaitan satu sama lain. Sapriya dalam Wahid (2016) mengemukakan beberapa indikator keterampilan sosial diantaranya keterampilan meneliti, keterampilan berfikir, keterampilan berpartisipasi sosial dan keterampilan berkomunikasi sedangkan indikator keterampilan sosial menurut Walker \& Mc.Connel dalam Suharmini, Purwandari, Mahabbati, \& Purwanto (2017) kemampuan empati, komunikasi dan interaksi, perilaku membantu, dan perilaku mau belajar. Sejalan dengan pendapat tersebut, Maryani (2011) mengemukakan beberapa indikator keterampilan sosial yaitu berinteraksi, komunikasi, membangun tim/kelompok, menyelesaikan masalah dan mengendalikan diri. Peneliti disini menggunakan indikator keterampilan sosial yang dikemukakan oleh Maryani.

Permasalahan yang terjadi mengenai keterampilan sosial peserta didik di kelas berkaitan dengan sikap peserta didik pada saat pembelajaran. Berdasarkan penelitian yang telah dilakukan oleh Parji \& Andriani (2016) di kelas VI B SDN Nambangan Kidul Kota Madiun pada pembelajaran IPS pada saat pembelajaran peserta didik kurang memperhatikan, kurang konsentrasi dan kurang bekerjasama. Peserta didik masih menunjukkan sikap egois, 
individualis. Begitupun peserta didik yang paham mengenai materi cenderung acuh pada peserta didik yang kurang paham sehingga kerjasama kurang terjalin dan keterampilan sosial kurang berkembang. Permasalahan serupa terjadi pada penelitian yang dilakukan oleh Ainiyah, Rusijono, \& Subroto (2019) yang mana pada hasil observasinya di SDN Kedungsumur I dan SDN Kedungsumur III pada pembelajaran IPS peserta didik kurang terlibat dalam proses pembelajaran sehingga terlihat bosan dan tidak bersemangat. Beberapa peserta didik yang pandai cenderung tidak percaya pada temannya untuk mengerjakan tugas sehingga tidak terjadi kegiatan berdiskusi. Hal tersebut menyebabkan peserta didik yang memiliki kemampuan sedang menjadi tidak percaya diri untuk mengembangkan kemampuan mereka, takut untuk bertanya, berpendapat, menjawab pertanyaan. Hal tersebut menunjukkan bahwa kurangnya kerjasama, sikap saling menghargai dan kurang komunikatif dalam pembelajaran sehinga keterampilan sosial cukup sulit berkembang.

Peneliti melakukan penelitian pada kelas V SDN 1 Purwawinangun. Berdasarkan hasil observasi yang dilakukan pada tanggal 26 Januari 2019 mengenai keterampilan sosial di kelas saat proses pembelajaran jika dilihat dari perilaku peserta didik dapat dikategorikan masih pasif, karena sebagian besar peserta didik hanya menerima materi-materi yang disampaikan oleh guru, dan mengerjakan latihan yang diperintahkan oleh guru. Adapun beberapa hal yang belum dipahami, berdasarkan hasil angket sebanyak $60 \%$ peserta didik masih bersikap acuh ketika guru memberikan kesempatan untuk bertanya. Sikap seperti diam, tidak merespon guru yang memberikan kesempatan untuk bertanya. Selain itu, sebanyak $71,85 \%$ peserta didik masih merasa takut dan malu untuk bertanya pada guru ketika ada materi yang belum mereka pahami. Namun, terdapat beberapa peserta didik yang lebih senang bertanya pada teman sebangkunya tentang materi yang belum dipahami serta lebih memiliki tindakan diam dan acuh ketika guru memberikan kesempatan untuk bertanya. Hal serupa terjadi ketika kegiatan berdiskusi, dilihat dari hasil angket bahwa sebanyak $60,74 \%$ peserta didik ketika berdiskusi, hanya duduk mendengarkan tanpa mengajukan pertanyaan. Sikap tersebut memperlihatkan bahwa interaksi yang terjadi saat proses pembelajaran hanya satu arah, tidak ada umpan balik yang dilakukan oleh peserta didik saat proses pembelajaran. Salah satu faktor penyebabnya adalah peserta didik masih merasa takut dan malu untuk mengemukakan ide atau pendapatnya, terbukti pada hasil angket yang menujukkan presentase sebanyak 54,07\% yang menyetujui pernyataan bahwa mereka merasa takut dan malu untuk mengemukakan ide atau pendapat, kecuali ketika mereka diminta oleh teman dan gurunya. Hal itu sejalan dengan hasil angket yang menujukkan bahwa sebanyak $71,11 \%$ untuk pernyataan yang menyatakan bahwa mereka hanya memberikan pendapat jika diminta oleh guru atau teman diskusinya.

Semua hal tersebut, seperti peserta didik masih bersikap acuh ketika guru memberikan kesempatan untuk bertanya, merasa takut dan malu untuk bertanya pada guru ketika ada materi yang belum mereka pahami, hanya duduk mendengarkan tanpa mengajukan pertanyaan ketika berdiskusi dan merasa takut dan malu untuk mengemukakan ide atau pendapat merupakan sikap yang menunjukkan bahwa dalam kegiatan pembelajarannya masih pasif dan interaksi dan komunikasi yang terjalin belum cukup optimal. Sikap tersebut pun bertentangan dengan karakterikstik keterampilan sosial seperti yang dikemukakan oleh Kaili Chen dalam Lujianto (2009) yang mengemukakan bahwa karakteristik keterampilan sosial beberapa diantaranya adalah merespon orang lain dan adanya interaksi maupun komunikasi yang bersifat timbal balik. Artinya, ketika peserta didik mengacuhkan guru ketika bertanya, takut dan malu untuk bertanya, menjawab pertanyaan ataupun berpendapat maka dapat disimpulkan bahwa interaksi dan komunikasi yang terjadi dalam pembelajaran kurang optimal. 
Pada saat proses pembelajaran pun terdapat beberapa peserta didik yang bercanda dan sibuk dengan kegiatannya sendiri di belakang ketika guru sedang memaparkan materi, dibuktikan dengan hasil angket sebanyak $33,33 \%$ peserta didik melakukan kegiatan lain yang tidak berhubungan dengan materi pelajaran. Hal ini pun bertentangan pada salah satu karakteristik keterampilan sosial yang dikemukakan oleh Elksnin \& Elksnin dalam Perdani (2014) yang mengemukakan bahwa salah satu karakterstik keterampilan sosial adalah perilaku yang berhubungan dengan diri sendiri seperti kemampuan mengatur diri atau mengntrol diri pada situasi tertentu. Ketika peserta didik belum cukup bisa untuk mengontrol diri mereka sendiri pada saat kegiatan pembelajaran, maka dapat dikatakan keterampilan sosialnya pun belum berkembang secara optimal. Dari hasil observasi dan hasil presentase dari angket yang telah dibagikan dan disesuaikan dengan teori-teori yang relevan maka dapat dikatakan bahwa keterampilan sosial peserta didik pada kegiatan pembelajaran kelas V di SD Negeri 1 Purwawinangun masih tergolong rendah. Maka dari itu, diperlukan solusi untuk mengatasi masalah tersebut salah satunya yaitu dengan diterapkannya model kooperatif tipe Time Token Arends.

Slavin (2010) menjelaskan bahwa model pembelajaran Time Token Arends merupakan salah satu pendekatan struktural dalam pembelajaran kooperatif yang dirancang untuk mempengaruhi pola interaksi peserta didik. Tipe pembelajaran ini dimaksudkan sebagai alternatif untuk mengajarkan keterampilan sosial yang bertujuan untuk menghindari peserta didik yang mendominasi atau diam sama sekali dan menghendaki peserta didik untuk saling membantu dalam kelompok kecil dan lebih dicirikan oleh penghargaan kooperatif daripada individu. Pada model Kooperatif tipe Time Token Arends ini setiap peserta didik diberi kupon berbicara, baik itu untuk menjawab pertanyaan maupun mengemukakan pendapat, disamping menuntut peserta didik untuk mengemukakan pendapat dan bertanya (berkomunikasi), model ini pun akan membantu peserta didik untuk berinteraksi, bekerja sama dengan kelompoknya masing-masing dalam menyelesaikan masalah atau tugas yang diberikan. Sehingga, dengan diterapkannya model pembelajaran kooperatif tipe Time Token Arends ini diharapkan peserta didik mampu mengoptimalkan keterampilan sosial di kelas saat proses pembelajaran.

Hal tersebut dapat terbukti pada penelitian yang telah dilakukan oleh Wijayanti (2018) yang menyimpulkan bahwa The implementation of Time Token Learning Model was effective for elementary school students based on the two parameters, namely, students' activities and lesson plan implementation. The learning model had successfully stimulated the students to be active learners that were expressed through arguing, solving problem, and collaborating activities. Hasil penelitian tersebut menjelaskan bahwa penggunaan atau penerapan model Time Token Arends ini efektif untuk diterapkan di Sekolah Dasar. Dapat dikatakan efektif karena model pembelajaran ini mampu merangsang peserta didik untuk menjadi pembelajar yang aktif, dilihat dengan pengungkapan pendapat, penambahan jawaban dalam berdiskusi, pemecahan masalah yang dikolaborasikan dengan kegiatan yang lain. Hal tersebut sejalan dengan hadil penelitian yang telah dilakukan oleh Ni'mah (2018) dengan hasil yang menunjukkan bahwa adanya pengaruh yang positif dan signifikan penerapan model cooperative learning tipe time token terhadap keterampilan sosial.

Berdasarkan masalah yang terjadi di kelas V SDN 1 Purwawinangun mengenai keterampilan sosial yang masih tergolong rendah maka peneliti berpendapat bahwa masalah tersebut harus segera mendapatkan solusi, karena keterampilan sosial merupakan salah satu kompetensi yang sangat penting untuk dikembangkan secara optimal saat kegiatan pembelajaran dengan memberi kesempatan peserta didik untuk mengembangkan keterampilan sosial yang dimilikinya, karena ketika peserta didik tidak mencoba menggali keterampilannya seperti bertanya, mengajukan pendapat, bekerjasama dan mengendalikan diri maka keterampilan sosialnya pun akan sulit berkembang. Maka dari itu, salah satu 
Syofi Syofiyah Dewi, Arrofa Acesta, \& Heru Purnomo

PENGARUH MODEL PEMBELAJARAN KOOPERATIF TIPE TIME TOKEN ARENDS

TERHADAP KETERAMPILAN SOSIAL PESERTA DIDIK DI KELAS

solusinya yaitu dengan menggunakan model pembelajaran kooperatif tipe Time Token Arends.

\section{METODE PENELITIAN \\ Desain Penelitian}

Penelitian ini termasuk ke dalam penelitian Quasi Eksperimen. Desain penelitian yang digunakan adalah Pretest-Posttest Non-equivalent Group Design yang dapat digambakan sebagai berikut.

Tabel 1. Desain Pre test- Post test Non-Equivalent Design

\begin{tabular}{lll}
\multicolumn{3}{c}{ Sugiyono $(2017: 116)$} \\
\hline Eksperimen & $\mathbf{O}_{\mathbf{1}} \mathbf{X}$ & $\mathbf{O}_{\mathbf{2}}$ \\
\hline Kontrol & $\mathbf{O}_{\mathbf{3}}$ & $\mathbf{O}_{\mathbf{4}}$ \\
\hline
\end{tabular}

Keterangan:

$\mathrm{O}_{1}$ : Pengukuran keterampilan sosial kelas eksperimen

$\mathrm{O}_{2}$ : Pengukuran keterampilan sosial kelas ekperimen

$\mathrm{O}_{3}$ : Pengukuran keterampilan sosial kelas kontrol

$\mathrm{O}_{4}$ : Pengukuran keterampilan sosial kelas kontrol

$\mathrm{X}$ : Pembelajaran IPS melalui model pembelajaran kooperatif tipe Time Token Arends

\section{Tempat Penelitian}

Penelitian ini dilaksanakan di SDN 1 Purwawinangun yang terletak di Jalan Siliwangi Nomor 45 Kuningan. Untuk waktu penelitian, peneliti melakukan penelitian pada akhir bulan April sampai dengan awal bulan Mei 2019.

\section{Subjek Penelitian}

Subjek penelitian ini adalah kelas V SD Negeri 1 Purwawinangun sejumlah 49 peserta didik. Data yang akan diambil dalam penelitian ini dua kelas yaitu kelas VA dimana kelas tersebut menggunakan model pembelajaran pembelajaran kooperatif tipe Time Token Arends sebagai kelas eksperimen dan kelas VB sebagai kelas kontrol dengan menggunakan model pembelajaran langsung. Kelas VA berjumlah 24 peserta didik sedangkan kelas VB berjumlah 25 peserta didik.

\section{Teknik dan Instrumen Pengumpulan Data}

Data pada penelitian ini didapat dengan cara observasi terstruktur dengan menggunakan bantuan empat orang observer sehingga setiap observer memegang beberapa nama peserta didik untuk diamati. Instrumen yang digunakan dalam penelitian ini adalah lembar observasi mengenai beberapa indikator dari keterampilan sosial diantaranya berinteraksi, komunikasi, membangun tim/kelompok, menyelesaikan masalah dan mengendalikan diri. Alat bantu yang digunakan yaitu skala penilaian menggunakan skala Likert dengan rentang 1-5 disertai dengan rubrik penilaiannya. Instrumen maupun rubrik yang digunakan sudah divalidasi dari tiga ahli sehingga dapat mengukur apa yang akan diukur. Untuk teknik analisisnya pada penelitian ini menggunakan uji prasyarat analisis yaitu uji normalitas dengan Chi Kuadrat dan uji homogenitas. Untuk uji hipotesis, peneliti menggunakan uji $\mathrm{t}$ dua sampel independen untuk mendeksripsikan perbedaan dan $\mathrm{n}$-gain dengan tujuan untuk mendeskripsikan peningkatan antara kelas eksperimen dan kelas kontrol. 


\section{Teknik Analisis Data}

Uji t dua sampel independen

Uji hipotesis pada penelitian ini adalah dengan menggunakan uji t dua sampel independen untuk mengetahui perbedaan keterampilan sosial peserta didik antara kelas eksperimen dengan kelas kontrol, dengan rumus:

Sugiyono (2017: 273)

$$
\mathrm{t}=\frac{\overline{\mathrm{X}}_{1}-\overline{\mathrm{X}}_{2}}{\sqrt{\frac{\left(\mathrm{n}_{1}-1\right) \mathrm{s}_{1}^{2}+\left(\mathrm{n}_{2}-1\right) \mathrm{s}_{2}^{2}}{\mathrm{n}_{1}+\mathrm{n}_{2}-2}\left(\frac{1}{\mathrm{n}_{1}}+\frac{1}{\mathrm{n}_{2}}\right)}}
$$

\section{Keterangan:}

$\overline{\mathrm{X}}_{1}$ : Rata-rata sampel 1

$\overline{\mathrm{X}}_{2}$ : Rata-rata sampel 2

$\mathrm{s}_{1}^{2}$ : Varians sampel 1

$\mathrm{s}_{2}^{2}$ : Varians sampel 2

$\mathrm{n}_{1}$ : Jumlah sampel 1

$\mathrm{n}_{2}$ : Jumlahsampel 2

$\mathrm{N}$-gain

Untuk mengetahui peningkatan dan kriteria keterampilan sosial peserta didik di kelas, maka digunakan rumus n-gain dari Hake sebagai berikut.

Hake (1998: 65)

$$
\mathrm{G}=\frac{\mathrm{S}_{f}-\mathrm{S}_{i}}{100-\mathrm{S}_{i}}
$$

Keterangan:

$\mathrm{S}_{f}:$ Skor post-test

$S_{i}$ : Skor pre-test

Adapun untuk kriteria klasifikasi n-gain menggunakan klasifikasi Hake (1998: 65) yang dapat dilihat pada Tabel 2 di bawah ini.

\begin{tabular}{ll}
\multicolumn{2}{c}{ Tabel 2. Kriteria Klasifikasi N-Gain } \\
\hline Koefisien n-gain & Kriteria \\
\hline $\mathbf{G}>\mathbf{0 , 7}$ & Tinggi \\
$\mathbf{0 , 3} \leq \mathbf{G} \leq \mathbf{0 , 7}$ & Sedang \\
$\mathbf{G}<\mathbf{0 , 3}$ & Rendah \\
\hline
\end{tabular}

\section{HASIL PENELITIAN DAN PEMBAHASAN \\ Hasil Penelitian}

Data yang diperoleh adalah data mengenai penilaian kondisi awal yang bertujuan untuk melihat bagaimana kondisi awal keterampilan sosial peserta didik di kelas saat proses pembelajaran berlangsung dan kondisi akhir setelah diberikan treament di kelas eksperimen. Kedua penilaian tersebut dapat memberikan informasi mengenai pengaruh dari perlakuan yang telah diberikan. Berikut rekapan nilai hasil penelitian yang diperoleh dari kelas eksperimen dan kelas kontrol.

Data pre-test diambil untuk mengetahui kondisi awal keterampilan sosial peserta didik di kelas V-A sebagai kelas eksperimen sedangkan data post-test diambil untuk mengetahui kondisi akhir keterampilan sosial di kelas pada saat kegiatan pembelajaran 
setelah diberikan perlakuan berupa penerapan model kooperatif tipe Time Token Arends. Berikut disajikan rekapan hasil nilai pre-test dan post-test dengan rekapan total, rata-rata, nilai tertinggi dan nilai terendah pada kelas eksperimen sebagai berikut.

Tabel 3. Hasil Pre-Test dan Post-Test Kelas Eksperimen

\begin{tabular}{llll}
\hline No & Keterangan & \multicolumn{2}{c}{ Nilai } \\
\cline { 3 - 4 } & & Pre-Test & Post-Test \\
$\mathbf{1}$ & Total & 1344 & 2096 \\
$\mathbf{2}$ & Rata-Rata & 56,3 & 87,3 \\
$\mathbf{3}$ & Nilai Tertinggi & 80 & 95 \\
$\mathbf{4}$ & Nilai Terendah & 39 & 78 \\
\hline
\end{tabular}

Berdasarkan data pre-test dan post-test pada Tabel 3 dapat diketahui kondisi awal keterampilan sosial peserta didik di kelas didapatkan nilai rata-rata 56,3 dengan nilai tertinggi 80 dan nilai terendah 39 sedangkan kondisi akhir setelah diberikan perlakuan berupa penerapan model kooperatif tipe Time Token Arends diperoleh nilai rata-rata 87,3 dengan nilai tertinggi 95 dan nilai terendah 78 .

Data pre-test diambil untuk mengetahui kondisi awal keterampilan sosial peserta didik di kelas V-B sebagai kelas kontrol sedangkan data post-test diambil untuk mengetahui kondisi akhir keterampilan sosial di kelas pada saat kegiatan pembelajaran. Berikut disajikan rekapan hasil nilai pre-test dan post-test disertai perhitungan gain score pada kelas kontrol sebagai berikut.

Tabel 4. Hasil Pre-Test dan Post-Test Kelas Kontrol

\begin{tabular}{llll}
\hline \multirow{2}{*}{ No } & Keterangan & \multicolumn{2}{c}{ Nilai } \\
\cline { 3 - 4 } & & Pre-Test & Post-Test \\
$\mathbf{1}$ & Total & 1491 & 1884 \\
$\mathbf{2}$ & Rata-Rata & 56,6 & 75,6 \\
$\mathbf{3}$ & Nilai Tertinggi & 83 & 89 \\
$\mathbf{4}$ & Nilai Terendah & 43 & 60 \\
\hline
\end{tabular}

Berdasarkan data pre-test dan post-test pada Tabel 4 dapat diketahui kondisi awal (pre-test) keterampilan sosial peserta didik di kelas didapatkan nilai rata-rata 56,6 dengan nilai tertinggi 83 dan nilai terendah 43 sedangkan kondisi akhir (post-test) diperoleh nilai rata-rata 75,6 dengan nilai tertinggi 89 dan nilai terendah 60 .

Data yang sudah diperoleh dilanjutkan dengan uji prasyarat analisis dengan dilakukannya uji normalitas dan uji homogenitas. Berdasarkan uji prasyarat, dapat diketahui bahwa data tersebut berdistribusi normal, artinya data tersebut berasal dari distribusi yang normal, sehingga dapat dilanjutkan dengan uji prasyarat selanjutnya yaitu homogenitas. Berdasarkan uji homogenitas, dapat disimpulkan bahwa kedua data tersebut bersifat homogen. Data berdistribusi normal dan homogen, maka uji statistik pun dapat dilanjutkan dengan menggunakan uji t dua sampel indepedent dengan hasil sebagai berikut:

Tabel 5. Hasil Uji t dua sampel independen

\begin{tabular}{lllll}
\hline Kelas & Rata-rata & Varians & $\mathbf{t}_{\text {hitung }}$ & $\mathbf{t}_{\text {tabel }}$ \\
\hline Eksperimen & 87,3 & 28,80 & 6,57 & 1,677 \\
Kontrol & 75,6 & 47,91 & & \\
$\begin{array}{l}\mathbf{t}_{\text {hitung }}>\mathbf{t}_{\text {tabel }} \\
\text { maka Ha diterima dan } \mathbf{H}_{\mathbf{o}} \text { ditolak }\end{array}$ & & \\
\hline
\end{tabular}


Berdasarkan Tabel 5 di atas yang menunjukkan bahwa hasil uji t dua sampel independent diperoleh hasil nilai rata-rata kelas eksperimen 87,3 dengan varians 28,80 dan pada kelas kontrol diperoleh rata-rata 75,6 dengan varians 47,91. Maka setelah dilakukan

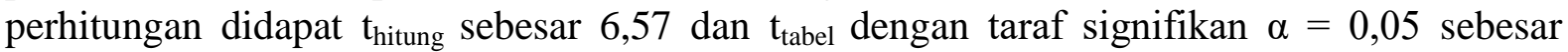
1,677. Karena $t_{\text {hitung }}>t_{\text {tabel }}$ atau 6,57 $>1,677$ maka Ha diterima dan Ho ditolak. Artinya, terdapat perbedaan keterampilan sosial peserta didik antara kelas yang menggunakan model kooperatif tipe Time Token Arends dengan kelas yang menggunakan model pembelajaran langsung.

Untuk mengetahui peningkatan keterampilan peserta didik di kelas, maka digunakan rumus $\mathrm{N}-$ Gain dari Hake. Berikut rekapitulasi hasil perhitungan $\mathrm{N}-$ Gain.

Tabel 6. Hasil N-Gain dan Klasifikasi N-Gain

\begin{tabular}{lllll}
\hline Kelas & Pre-test & Post-test & N-Gain & Kriteria \\
\hline Eksperimen & 56,3 & 87,3 & 0,72 & Tinggi \\
Kontrol & 56,6 & 75,6 & 0,40 & Sedang \\
\hline
\end{tabular}

Berdasarkan Tabel 6 di atas yang menunjukkan bahwa pada kelas eksperimen dengan rata-rata nilai Pre-test 56,3 dan Post-test 87,3 diperoleh $\mathrm{N}$-Gain sebesar 0,72 dengan kriteria tinggi sedangkan pada kelas kontrol dengan rata-rata nilai Pre-test 56,6 dan Post-test 75,6 diperoleh N-Gain sebesar 0,40 dengan kriteria sedang.

\section{Pembahasan}

Pada penelitian ini, model kooperatif tipe Time Token Arends diterapkan di kelas V A sebagai kelas eksperimen sedangkan pada kelas kontrol diterapkan model pembelajaran langsung dalam mata pelajaran Ilmu Pengetahuan Sosial. Tujuan dilakukannya penelitian ini adalah untuk mengetahui apakah model kooperatif tipe Time Token Arends ini memiliki pengaruh terhadap keterampilan sosial peserta didik di kelas pada mata pelajaran Ilmu Pengetahuan Sosial dengan dilihat dari perbedaan dan peningkatan pada kelas eksperimen dan kelas kontrol. Penelitian dilakukan selama enam hari. Tiga hari untuk melihat kondisi awal baik di kelas eksperimen maupun kontrol dan tiga hari lainnya untuk melihat kondisi akhir.

Pembelajaran di kelas kontrol dimulai dengan kegiatan berdoa terlebih dahulu yang dipimpin oleh ketua kelas dan dilanjutkan dengan kegiatan menyimak penjelasan dari guru. Pada kondisi tersebut guru memaparkan materi-materi dengan sesekali bertanya pada peserta didik, namun hanya beberapa saja peserta didik yang menjawab, sedangkan yang lainnya memilih diam dan ada pula yang melakukan kegiatan lain diluar pembelajaran, bahkan mengobrol dengan teman sebangkunya, yang mana pada kondisi tersebut seringkali guru menegur ketika suara yang dikeluarkan oleh peserta didik terdengar cukup keras. Setelah guru menyampaikan materi, guru memberikan tugas atau latihan pada peserta didik, peserta didik pun langsung mengerjakannya secara individu, dilanjut dengan pembahasan secara menyeluruh, artinya tugas atau latihan tersebut dibahas secara bersama-sama dengan guru menyebutkan kembali pertanyaannya dan hanya beberapa peserta didik yang mengkomunikasikan jawaban yang diperolehnya. Terlihat disini beberapa peserta didik mendominasi kegiatan pembelajaran.

Kondisi tersebut berbeda dengan kondisi setelah diberikan perlakuan dengan menerapkan model kooperatif tipe Time Token Arends. Penerapan model kooperatif tipe Time Token Arends di kelas VA berdasarkan hasil lembar observasi yang terdiri dari 5 indikator seperti indikator berinteraksi, berkomunikasi, membangun kelompok, menyelesaikan masalah dan mengendalikan diri. Pada setiap indikatornya terdapat empat sub indikator, dengan jumlah total aspek yang diamati sebanyak 20 aspek. Pembelajaran pertama di kelas eksperimen dimulai dengan kegiatan berdoa yang dipimpin oleh ketua kelas, peserta didik 
menyimak tujuan pembelajaran yang disampaikan oleh guru dilanjutkan dengan pembagian kelompok dan penjelasan mengenai aturan main mengenai model kooperatif tipe Time Token Arends ini sekaligus memberikan Lembar Kerja Siswa mengenai usaha ekonomi untuk dikerjakan dan didiskusikan bersama-sama. Selama berdiskusi, peserta didik menujukkan sikap saling bekerja sama, saling membantu, peduli dengan anggota kelompoknya.

Hal tersebut serupa dengan hari kedua penelitian, saat jam pertama di kelas eksperimen dalam materi kegiatan ekonomi (produksi, distribusi dan konsumsi), peserta didik terlihat sangat antusias untuk mengikuti kegiatan pembelajaran. Pada pelaksanaannya, baik interaksi antara peserta didik dengan guru maupun peserta didik dengan peserta didik sudah begitu terlihat. Sikap saling membangun tim dan bekerjasama nya pun terlihat jelas, yang mana antar peserta didik saling membantu temannya untuk menggunakan kupon berbicara yang dimilikinya. Adapun jumlah peserta didik yang bertanya, semakin bertambah. Mereka saling memberikan umpan balik, walaupun masih terdapat beberapa peserta didik yang hanya menggunakan dua atau tiga kupon untuk mengemukakan pendapat.

Pada hari ketiga di kelas eksperimen, pada materi menghargai kegiatan usaha ekonomi orang lain. Ternyata kegiatan pembelajaran yang dilakukan dua hari kemarin memberikan efek yang sangat baik untuk peserta didik. Peserta didik sangat antusias untuk saling berlomba menggunakan kupon berbicaranya. Saling menyimak, saling memberikan umpan balik antara peserta didik dengan peserta didik lain maupun antara peserta didik dengan guru. Peserta didik secara bebas mengemukakan pendapat mengenai cara menghargai kegiatan usaha ekonomi orang lain. Peserta didik semakin menunjukkan sikap saling bekerjasama, saling membantu dengan teman kelompok kecilnya. Hal itu dilakukan agar tim atau peserta didik tersebut menjadi tim atau kelompok dengan sisa kupon paling sedikit.

Scefeldt \& Barbour dalam Bali (2017) mengemukakan bahwa keterampilan sosial merupakan kecakapan dalam berkomunikasi, saling berbagi informasi dengan yang lain, jika dilihat dari lima indikator yang menjadi patokan utama dalam menilai keterampilan sosial peserta didik di kelas. Untuk indikator pertama yaitu mengenai indikator berinteraksi dapat dideskripsikan bahwa interaksi yang terjalin pada kelas eksperimen lebih sering daripada kelas kontrol. Misalnya saja, pada aspek pandangan fokus pada teman maupun guru yang sedang berbicara, peserta didik pada kelas eksperimen lebih sering memfokuskan pandangan dan menyimak teman ataup guru yang berbicara. Hal itu dilakukan karena peserta didik dituntut untuk menggunakan kupon berbicara yang dimilikinya baik itu kupon bertanya, memberikan pendapat atau menjawab pertanyaan. Untuk bisa menggunakan salah satu kupon berbicara tersebut tentunya pandangan peserta didik harus lebih dulu fokus dan menyimak apa yang teman atau gurunya bicarakan sehingga peserta didik dapat menangkap apa yang dibicarakan dan mendorong dirinya untuk bertanya, menjawab pertanyaan ataupun memberikan pendapat. Begitupun dengan indikator kedua yaitu berkomunikasi yang mana komunikasi di kelas eksperimen saat proses pembelajaran terjalin secara dua arah, artinya dalam kegiatan pembelajaran tersebut terjadinya umpan balik baik dari guru dengan peserta didik ataupun peserta didik dengan peserta didik. Sehingga pada kegiatan pembelajaran tidak ada peserta didik yang mendominasi, hampir semua peserta didik mampu mengkomunikasikan jawaban, walaupun untuk mengemukakan pendapat masih beberapa peserta didik yang belum dapat melakukannya karena terbatas dengan waktu dan dorongan dari dirinya. Hal tersebut sesuai dengan kecakapan keterampilan sosial yang dikemukakan oleh Scefeldt \& Barbour di atas. Artinya, ketika peserta didik sudah mulai mampu berkomunikasi, saling berbagi informasi dengan yang lain melalui bertanya, menjawab ataupun mengemukakan pendapat maka keterampilan sosial yang dimilikinya dapat dikatakan mulai berkembang. 
Pada indikator ketiga yaitu membangun tim atau kelompok. Indikator ini terlihat sangat menonjol perbedaannya dengan kelas kontrol. Pada kelas eksperimen karena memang menggunakaln salah satu tipe model kooperatif, maka kegiatan pembelajarannya pun dilakukan secara berkelompok. Sedangkan pada kelas kontrol tidak, pada kelas kontrol peserta didik dituntut untuk memiliki rasa peka untuk membangun tim atau kelompok untuk menyelesaikan tugas yang diberikan. Namun, ketika peserta didik tersebut tidak diarahkan atau dikondisikan untuk saling bekerjasaama untuk tingkat sekolah dasar masih belum terlihat, sehingga penyelesaian tugasnya pun masih secara individu. Berbeda dengan kelas kelas eksperimen yang diarahkan untuk berkelompok, sehingga peserta didik hanya dituntut untuk membangun kelompok yang sudah jelas siapa anggotanya, siapa timnya dan bagaimana caranya menyelesaikan tugas yang diberikan. Indikator ketiga ini berhubungan dengan Indikator keempat yaitu menyelesaikan masalah, pada kelas ekperimen jelas permasalahan yang dihadapi peserta didik dapat lebih cepat terselesaikan, karena dilakukan secara bersamasama dan dilakukan dengan berbagai cara untuk menyelsaikannya, dengan membaca buku kembali dan dengan berdiskusi. Hal tersebut relevan dengan kemampuan keterampilan sosial yang dikemukakan oleh Amrotunajah \& Masruri (2015) bahwa seseorang yang memiliki keterampilan sosial dikatakan jika seseorang tersebut mampu bergaul, bekerjasama dengan orang lain sehingga terjadi ikatan nonfisik untuk menyelesaikan masalah yang terjadi.

Hal itu serupa dengan indikator yang kelima mengenai mengendalikan diri. Pada kelas eksperimen peserta didik dituntut untuk menggunakan kupon berbicaranya, saling bekerjasama setiap anggota kelompok, saling menjaga, saling peduli pada anggota kelompok sehingga pengendalian diri yang dilakukan pun dapat dikondisikan secara baik. Misalnya pada aspek pengenadalian diri untuk tidak melakukan kegiatan lain diluar kegiatan pembelajaran. Hal itu terlihat jelas, karena pada kelas eksperimen ini peserta didik disibukkan dengan diskusi, menyimak apa yang sedang dibicarakan agar dapat menggunakan kupon berbicaranya. Untuk menjawab, menambahkan jawaban atau untuk berpendapat. Sehingga kesempatan peserta didik untuk melakukan kegiatan lain diluar kegiatan pembelajaran sangat kecil. Hal tersebut berarti, pengendalian diri sebagai indikator keterampilan sosial pada peserta didik mulai berkembang baik pada saat kegiatan pembelajaran. Elksnin \& Elksnin dalam Perdani (2014) mengemukakan bahwa keterampilan sosial mencakup perilaku yang berhubungan dengan diri sendiridalam situasi sosial tertentu. Jadi, ketika peserta didik mampu mengendalikan dirinya pada situasi tertentu, pada saat kegiatan pembelajaran misalnya maka menandakan bahwa keterampilan peserta didik tersebut mulai berkembang.

Dari penggunaan kupon berbicara tersebut membuat peserta didik termotivasi untuk saling bekerjasama menghabiskan kartu yang dimilikinya. Interaksi yang terjalin pun dua arah, selain itu peserta didik mulai dapat mengendalikan dirinya pada saat kegiatan pembelajaran dengan tidak melakukan kegiatan lain diluar pembelajaran, karena peserta didik akan disibukkan dengan bekerjasama, berdiskusi mencari jawaban dan menyimak apa yang teman lain atau guru kemukakan sehingga dapat bertanya, mengemukakan pendapat maupun menjawab pertanyaan, sehingga ketika peserta didik dapat melakukan beberapa aspek dalam indikator tersebut keterampilan sosial peserta didik di kelas dapat berkembang secara optimal.

Pada saat penyusunan dan pelaksanaan penelitian ini, peneliti memiliki keterbatasan. Keterbatasan dalam penelitian ini beberapa diantaranya adalah: (1) faktor lain yang ikut mempengaruhi keterampilan sosial peserta didik di kelas tidak diteliti. (2) keterampilan sosial yang diteliti hanya terbatas pada indikator keterampilan sosial peserta didik di kelas. (3) model Time Token Arends belum tentu efektif jika digunakan pada kelas dengan jumlah peserta didik banyak dan tidak semua topik mata pelajaran dapat diterapkan dengan model ini. 


\section{SIMPULAN DAN SARAN}

Berdasarkan hasil penelitian dan analisis data maka diperoleh kesimpulan pada penelitian ini. Hasil uji t dua sampel independent menunjukkan bahwa terdapat perbedaan keterampilan sosial peserta didik di kelas eksperimen yang menggunakan model kooperatif tipe Time Token Arends dengan kelas kontrol yang mengunakan model pembelajaran langsung. Untuk peningkatannya yang dilakukan dengan perhitungan rumus N-Gain diperoleh N-Gain sebesar 0,72 untuk kelas eksperimen yang apabila dimasukkan ke dalam kriteria klasifikasi $\mathrm{N}$-Gain termasuk ke dalam kriteria tinggi dan untuk kelas kontrol diperoleh N-Gain sebesar 0,40 yang apabila dimasukkan ke dalam kriteria klasifikasi N-Gain termasuk ke dalam kriteria sedang. Hal itu menunjukkan bahwa peningkatan di kelas eksperimen lebih besar daripada di kelas kontrol. Karena terdapat perbedaan dan peningkatan di kelas eksperimen setelah diberikan perlakuan, maka model kooperatif tipe Time Token Arends terbukti berpengaruh terhadap keterampilan sosial peserta didik di kelas.

Hasil penelitian ini dapat digunakan sebagai salah satu referensi untuk penelitian yang sejenis. Bagi peneliti lain dapat digunakan sebagai masukan untuk mengembangkan penelitian yang telah dilakukan dengan model pembelajaran maupun indikator lain dan aspek keterampilan sosial yang lebih kompleks serta rentang waktu yang lebih panjang tentunya dengan karakteristik peserta didik yang berbeda. 


\section{DAFTAR PUSTAKA}

Ainiyah, N., Rusijono, \& Subroto, W. T. (2019). Pengaruh model pembelajaran kooperatif tipe talking chips terhadap keterampilan sosial dan hasil belajar ips siswa kelas IV sekolah dasar. Jurnal Review Pendidikan Dasar. 5 (1). Retrieved from link https://journal.unesa.ac.id/index.php/PD/article/view/4917/2682.

Bali, M. M. E. I. (2017) Model interaksi sosial alam mengelaborasi keterampilan sosial. Jurnal Pedagogik, 4 (1), 211-227. Retrieved from link https://ejournal.unuja.ac.id/index.php/pedagogik/article/view/19/19.

Hake, Richard. (1998). Interactive-engagement versus traditional methods: a six-thousandstudent survey of mechanics test data for introductory physics courses. American Journal of Physics. 66 (1), 64-74. Retrieved from link https://www.researchgate.net/publication/228710512_Interactive-

Engagement_Versus_Traditional_Methods_A_Six-Thousand-

Student_Survey_of_Mechanics_Test_Data_for_Introductory_Physics_Courses.

Maryani, E. (2011). Pengembangan program pembelajaran ips untuk peningkatan keterampilan sosial. Bandung: Alfabeta.

Ni'mah, F. H. (2018). Pengaruh time token terhadap hasil belajar ips dan keterampilan sosial. Jurnal Pendidikan Guru Sekolah Dasar. 35 (7), 3447-3457. Retrieved from link http://journal.student.uny.ac.id/ojs/index.php/pgsd/article/viewFile/13917/13516.

Parji \& Andriani. R. E. (2016). Upaya peningkatan keterampilan sosial siswa melalui permainan tradisional congklak. Jurnal Studi Sosial, 1 (1), 14-23. Retrieved from link http://e-journal.unipma.ac.id/index.php/gulawentah/article/download/27/27.

Perdani, P. A. (2014). Peningkatan keterampilan sosial anak melalui permainan tradisional. Jurnal Pendidikan Usia Dini, 8 (1), 129-136. Retrieved from link https://media.neliti.com/media/publications/117972-ID-peningkatan-keterampilansosial-anak-mel.pdf.

Purnomo, Heru. (2019). Pengembangan bahan ajar materi penilaian otentik mata kuliah evaluasi pembelajaran. Didaktika Tauhidi: Jurnal Pendidikan Guru Sekolah Dasar, 6 (1), 73-85. Retrieved from link https://ojs.unida.ac.id/jtdik/article/view/1634/PENGEMBANGAN\%20BAHAN\%20 AJAR\%20MATERI\%20PENILAIAN\%20OTENTIK\%20MATA\%20KULIAH\%20 EVALUASI\%20PEMBELAJARAN.

Sardiman. (2004). Interaksi dan motivasi belajar mengajar. Jakarta: PT Raja Grafindo.

Slavin, R. E. (2010). Cooperative learning teori, riset, dan praktik. Terjemahan Narulita Yusron. Bandung: Nusa Media.

Sugiyono. (2017). Metode penelitian pendidikan. Bandung: Alfabeta

Suharmini, T., Purwandari, Mahabbati, A., \& Purwanto, H. (2017). Pengembangan pengukuran keterampilan sosial siswa sekolah dasar inklusif berbasis diversity 
Syofi Syofiyah Dewi, Arrofa Acesta, \& Heru Purnomo

PENGARUH MODEL PEMBELAJARAN KOOPERATIF TIPE TIME TOKEN ARENDS

TERHADAP KETERAMPILAN SOSIAL PESERTA DIDIK DI KELAS

awareness. Jurnal Penelitian ilmu Pendidikan. 10 (1), 11-21. Retrieved from link https://journal.uny.ac.id/index.php/jpip/article/view/16792/9938.

Thalib, B. S. (2010). Psikologi pendidikan berbasis analisis empiris aplikatif. Jakarta: Kencana Prenada Media Group.

Wahid, Abdul. (2016). Pengaruh strategi pembelajaran kooperatif jigsaw dan keterampilan sosial terhadap hasil belajar ips di SDN Kabupaten Bangkalan. Jinotep, 3 (1), 14-30. Retrieved from link http://journal2.um.ac.id/index.php/jinotep/article/view/2340/1405.

Wijayanti, I. L. Kasdi, A., \& Suhanadji (2018). The effectiveness of time token learning model for elementary school students. Advances in Social Science, Education and Humanities Research, 212 (6), 350. Retrieved from link https://www.atlantispress.com/proceedings/icei-18/55907511. 